\title{
Defoliation Levels Supported in Soybean Crop With No Harm on Productivity in the Municipality of Parauapebas
}

\author{
L. J. Damasceno ${ }^{1}$, V. F. A. Silva ${ }^{1}$, J. N. da Silva ${ }^{1}$, P. A. Silva ${ }^{1}$, C. C. Lima ${ }^{1}$, J. P. da Silva ${ }^{1}$, J. R. Galvão ${ }^{2}$, \\ N. C. Melo $^{3} \&$ G. F. Valente ${ }^{1}$ \\ ${ }^{1}$ Federal Rural University of Amazon, Parauapebas, Brazil \\ ${ }^{2}$ Institute of Agricultural Sciences, Federal Rural University of Amazon, Belém, Brazil \\ ${ }^{3}$ Department of Soil Science, Federal Institute of Amapá, Macapá, Brazil \\ Correspondence: V. F. A. Silva, Federal Rural University of Amazon, Bairro Cidade Nova (Caixa postal No 3017), \\ 68515-000, Parauapebas, Brazil. Tel: 94-9-9156-9961. E-mail: vicente.silva@ufra.edu.br
}

Received: May 30, 2019

doi:10.5539/jas.v11n17p227
Accepted: August 27, $2019 \quad$ Online Published: October 15, 2019

URL: https://doi.org/10.5539/jas.v11n17p227

\begin{abstract}
The reduction in the leaf area is one of the causes in the fall in soybean (Glycine max) productivity as it depends on the production of photoassimilates generated by the leaves, so any factor that interferes in its leaf area may affect the production. The attack of defoliating insects is among such factors. They cause a marked drop in grain yield due to its direct action, therefore, reducing the leaf area, consequently reducing the photosynthetic rate of the plant. The agronomic characteristics of the cultivars may interfere on the level of tolerance of the plant to this type of stress. The objective of this study was to evaluate the influence of defoliation levels on the vegetative and reproductive stages on the development and yield of grains in soybean cultivars. The experimental design was in randomized blocks, in a $2 \times 11 \times 2$ factorial scheme, with four replicates. Factors consisted of defoliation stage (vegetative and reproductive), treatment levels (T1-control plant and ten treatments of artificial defoliation) and soybean cultivars (BRS 9090 RR and BRS 8890 RR). The following variables were evaluated: grain yield, dry mass of the pod, leaf dry mass, stem and root dry mass, plant height, stem diameter, number of leaves per plant, length and width of roots. It was observed that the defoliation had a negative effect on the productivity components of the cultivars, with the highest decrease in the reproductive stage, except for the treatment R5, 100\% defoliation at the R5 stage, which was also reduced. In relation to the cultivars, the BRS 8890 RR was $27 \%$ better in grain yield in relation to BRS $9090 \mathrm{RR}$.
\end{abstract}

Keywords: Glycine max, leaf area reduction, productivity

\section{Introduction}

Soybean (Glycine max (L.) Merril) is one of the crops with the greatest growth in planted area in the Brazilian agro-industrial segment. Its expansion and establishment of agricultural frontiers was only possible due to the development of cultivars with high productivity, wide adaptation to the different edaphoclimatic conditions and resistance to pests and diseases (EMBRAPA, 2008).

The productivity of the soybean is directly related to the photosynthesis performed by the leaves, and the production of photoassimilates from the photosynthetic complex. However, the factor that limits the leaf area may compromise crop productivity (Peluzio et al., 2002; Li et al., 2006). The attack of a large variety of defoliating insects (Timsina et al., 2007), the incidence of diseases such as soybean rust (Debona et al., 2009) and the occurrence of inclement weather (Fazolin \& Estrela, 2003) are some of the factor that limits its production.

Studies that evaluate the influence of early defoliation on soybean yield through the analyses of the phenological stages in which the soybean was found (from the initial vegetative stage to the end of the reproductive period) and levels of defoliation (ranging from 0 to 100\%) have demonstrated since the non-occurrence of the response until $87 \%$ of grain yield (Ribeiro \& Costa, 2000; Parcianello et al., 2004).

Chemical control of defoliating insects should be avoided as it results in environmental pollution, occupational diseases, and an increase in the final cost of production. Thus, the identification of the period(s) of greater 
sensitivity of the crop to defoliation, resulting from the attack of the pest insects will result in a decrease in the number of pesticide applications, consequently, it will reduce environmental damage and the cost of production.

According to Gazzoni (1974), the most important characteristics in the reduction of grain production are the number of seeds per pod and the mass of the seeds. According to Santos $(1980,1983)$, total defoliation in full flowering causes a reduction in grain yield due to a reduction in the number of pods per plant.

The ability of soybean when submitted to defoliation depends very much on its genetic characteristics, on the stage of development of the plants, and on the intensity of the defoliation itself (Costa et al., 2003).

Some factors may compromise the appropriate photosynthetic process, such as the low radiation incident on the canopy, the attack of defoliating insects, diseases such as soybean rust, which causes early leaf fall, abiotic stresses such as drought, salinity and soil fertility (Pedigo et al., 1986; Li et al., 2006; Timsina et al., 2007; Debona et al., 2009).

The objective of this work was to evaluate the influence of defoliation levels on the vegetative and reproductive stages on the soybean yieldand to evaluate the agronomic characteristics of each stage.

\section{Material and Methods}

\subsection{Characterization of Experimental Area}

The experiment was conducted at the nursery at UFRA (Federal Rural University of Amazonia), in the municipality of Parauapebas, Pará, Brazil, from August 2017 to January 2018. The municipality is located at the geographical coordinates $49^{\circ} 51^{\prime} 19^{\prime \prime} \mathrm{W}$ latitude, $06^{\circ} 12^{\prime} 58^{\prime \prime} \mathrm{S}$ longitude, $197 \mathrm{~m}$ above sea level. The climate in the region is rated as Aw according to Koppen Geiger.

\subsection{Characterization of Soil}

A sample was collected for soil analysis. The material was air-dried, ground, homogenized and sieved through a 2-mm stainless steel mesh sieve. Then, three samples of compounds were collected, consisting of six simple samples. These samples were sent to the laboratory for the analysis.

The physical and chemical characteristics of the soil were as follows: $\mathrm{pH}\left(\mathrm{H}_{2} \mathrm{O}\right): 4.3 ; \mathrm{Ca}^{2+}: 2.1 \mathrm{cmolc} \mathrm{kg}^{-1} ; \mathrm{Mg}^{2+}$ : 1.2 cmolc kg-1 $\mathrm{Al}^{3+}: 4.09$ cmolc kg${ }^{-1} ; \mathrm{H}^{++} \mathrm{Al}^{3+}: 4.29$ cmolc kg-1$; \mathrm{K}^{+}: 0.32 \mathrm{cmg} \mathrm{kg}$; $\mathrm{Na}^{+}: 0.33$ cmolc kg-1; $10.10 \mathrm{mg} \mathrm{kg}^{-1}$; organic matter: $25.62 \mathrm{~g} \mathrm{~kg}^{-1}$. Clay $3.8 \mathrm{~g} \mathrm{~kg}^{-1}$, silt $2.2 \mathrm{~g} \mathrm{~kg}^{-1}$, coarse sand $1.7 \mathrm{~g} \mathrm{~kg}^{-1}$ and fine sand $2.3 \mathrm{~g} \mathrm{~kg}^{-1}$.

The chemical characteristics were determined according to EMBRAPA (1997) and the particle size was classified according to Gee and Bauder (1986). Soil classification and fertilizer sizing were carried out using the Agrophytos Solo SAAT software.

Soil amendment was performed 60 days before sowing using dolomitic limestone (PRNT 70\%), by raising base saturation to $70 \%$, with the standard dosage of $6.68 \mathrm{tha}^{-1}$ as recommended for soybean for the respective soil type (EMBRAPA, 2011). The basic fertilization was performed according to the recommendation of EMBRAPA (2011), with the standard dosage of $600 \mathrm{~kg} \mathrm{ha}^{-1}$ in 5-25-15 NPK formulation.

\subsection{Experimental Design}

The experiment was carried out in a completely randomized block design, factorial scheme $2 \times 11$ consisting of two soybean cultivars (BRS 8890 RR and BRS 9090 RR) and 11 treatments (1 Control Plant and 10 artificial defoliation) (Table 1), with 5 treatments at the vegetative stage and 5 in the reproductive stage with four replications, totaling 88 experimental units. The artificial defoliation in the plants was made for each phenological stage by using pruning shears. 
Table 1. Defoliation level treatments according to the phenologic stage of the plant

\begin{tabular}{ll}
\hline Treatment & Defoliation Level \\
\hline T1 & Control plant with no injuries \\
T2 & 01 cotyledon removal \\
T3 & 02 cotyledon removal \\
T4 & Removal of trefoil at V5 \\
T5 & Total defoliation at V6 stage \\
T6 & Removal of apical bud at V6 stage \\
T7 & Total defoliation-One open flower at any node on the main stem-R1 \\
T8 & Removal of 02 trefoil at R3-Pod from $0.5 \mathrm{~cm}$ to $2.0 \mathrm{~cm}$ on one of the four higher nodes on the main stem \\
T9 & To\% defoliation at R5-beginning of grain filing $(<10 \%$ seed filling $)$ on one of the four higher nodes on the main stem \\
T10 & \\
T11 & Total defoliation at R5-beginning of grain filing $(<10 \%$ de seed filling $)$ on one of the four higher nodes on the main stem \\
\hline
\end{tabular}

\subsection{Experimental Plots}

The experiment was conducted in a nursery using 50\% shading. The seeds were placed to germinate in black polyethylene bags with holes, with the capacity of 11 kilograms. For sowing, three seeds per bag were placed for subsequent thinning and conduction of a single plant until the end of the experiment.

The cultivars used in the study were BRS 8890 RR-glyphosate-tolerant transgenic soybean; cycle (maturation): 101 to 115 days; and BRS 9090 RR-transgenic soybean cultivar, which shows tolerance to the herbicide glyphosate; cycle (maturation): 100 to 127 days, both of determined growth.

The soybean seeds were treated with the fungicide/insecticide Standak Top $(1.5 \mathrm{~mL}$ per $\mathrm{kg}$ of seed $)$ and then inoculated two hours prior to sowing with Total Nitro Ultra inoculant, Turfoso solids, on August 17, 2018. A dose of $60 \mathrm{~mL}$ of the total Nitro Ultra inoculant per $100 \mathrm{~kg}$ of seeds was used. Treatments were homogenized in polyethylene bags. Monitoring and measurements were performed every day over the experiment.

In order to assure the maintenance of the homogeneous defoliation in each treatment, weekly applications of insecticides were carried out or whenever it was necessary to prevent any influence of pests that could change the required levels of defoliation.

The fungicides were also used in all treatments, whenever it was necessary according to the usual practices used by soybean farmers.

Harvest was carried done manually by cutting the plants at ground level on December 20, 2017, when they reached the R8 stage (Fehr \& Caviness, 1977), totaling 123 days after planting.

\subsection{Evaluated Characteristics}

The following variables were analyzed at the end of soybean crop cycle:

Plant height (PH): it was measured with tape measure from the ground level to the leaf rosette.

Principal stem diameter (SD): The diameter was obtained with the use of a digital caliper with an accuracy of 0.1 $\mathrm{mm}$, measuring at $5 \mathrm{~cm}$ above ground level.

Number of leaves (NL): all leaves of each plant were counted.

Root length and width (RL and RW): The root system was measured by using a measuring tape. Length and width of the root were determined.

Seed production $\left(\mathrm{kg} \mathrm{ha}^{-1}\right)$ : Pods of the plants were collected from each replicate. Then, the seeds were removed and pods were weighed and the values extrapolated to $\mathrm{kg} \mathrm{ha}^{-1}$. After harvest, the seeds were placed in an oven until reaching the commercial humidity of $13 \%$.

Pod dry mass: Pods were removed and weighed. An oven was used at $60^{\circ} \mathrm{C}$ for 36 hours.

Stem dry mass: The stems were removed and weighed, using a stove for 36 hours at $60{ }^{\circ} \mathrm{C}$. Leaf dry mass: An oven was used at $60^{\circ} \mathrm{C}$ for 36 hours.

Root dry mass: roots were removed, washed and weighed using an oven for 36 hours at $60^{\circ} \mathrm{C}$. 


\subsection{Data Analysis}

The statistical analysis of the results was performed using the Sisvar software (Ferreira et al., 2014), so that the data were submitted to analysis of variance and, if significant, the test of Tukey was used at $5 \%$ of probability for differentiation of means.

\section{Results and Discussion}

Table 2 shows that for the cultivars treatment there was an isolately significance only for the number of leaves (NL) and root width (RW). Regarding the levels of defoliation and interaction between cultivars and levels of defoliation, no significance was observed.

Table 2. Summary of analysis of variance and data average for plant height (PH), number of leaves (NL), stem diameter (SD), root length (RL), root width (RW), submitted to defoliation levels and soybean cultivars

\begin{tabular}{|c|c|c|c|c|c|c|}
\hline Variation Factors & & AP & $\mathrm{NF}$ & $\mathrm{CR}$ & RL & RW \\
\hline \multirow{3}{*}{ Cultivars (C) } & & $\mathrm{m}$ & un & \multicolumn{3}{|c|}{---------------------- cm ---------------------- } \\
\hline & BRS 8890 RR & 0.92 & $46.15 \mathrm{a}$ & 44.30 & $17.64 \mathrm{a}$ & 9.74 \\
\hline & BRS $9090 \mathrm{RR}$ & 0.91 & $30.21 \mathrm{~b}$ & 45.33 & $15.03 \mathrm{~b}$ & 9.99 \\
\hline \multirow{11}{*}{ Defoliation level (ND) } & $\mathrm{T} 1$ & 0.97 & 42.50 & 52.83 & 18.28 & 11.15 \\
\hline & $\mathrm{T} 2$ & 0.95 & 41.00 & 48.17 & 17.36 & 10.48 \\
\hline & $\mathrm{T} 3$ & 0.90 & 41.83 & 45.33 & 16.45 & 10.30 \\
\hline & $\mathrm{T} 4$ & 0.86 & 41.00 & 41.67 & 16.05 & 10.40 \\
\hline & $\mathrm{T} 5$ & 0.80 & 41.16 & 45.33 & 16.18 & 8.78 \\
\hline & T6 & 0.87 & 40.50 & 45.67 & 16.71 & 9.82 \\
\hline & $\mathrm{T} 7$ & 0.87 & 36.67 & 40.17 & 15.88 & 9.06 \\
\hline & $\mathrm{T} 8$ & 0.86 & 42.00 & 42.83 & 14.91 & 9.99 \\
\hline & T9 & 0.71 & 44.00 & 44.00 & 16.36 & 10.39 \\
\hline & $\mathrm{T} 10$ & 0.83 & 40.33 & 43.33 & 15.03 & 9.25 \\
\hline & T11 & 0.70 & 38.00 & 43.67 & 16.48 & 9.09 \\
\hline \multirow{3}{*}{ Test F } & $\mathrm{C}$ & $0.02^{\mathrm{NS}^{-}}$ & $6.91 *$ & $0.47^{\mathrm{NS}}$ & $19.35^{* *}$ & $0.28^{\mathrm{NS}}$ \\
\hline & ND & $0.98^{\mathrm{NS}}$ & $0.51^{\mathrm{NS}}$ & $1.88^{\mathrm{NS}}$ & $0.93^{\mathrm{NS}}$ & $0.69^{\mathrm{NS}}$ \\
\hline & $\mathrm{C} \times \mathrm{ND}$ & $2.29^{\mathrm{NS}}$ & $0.53^{\mathrm{NS}}$ & $0.87^{\mathrm{NS}}$ & $1.49^{\mathrm{NS}}$ & $0.88^{\mathrm{NS}}$ \\
\hline $\mathrm{CV}(\%)$ & & 10.25 & 24.53 & 13.60 & 14.76 & 19.61 \\
\hline
\end{tabular}

Note. $\mathrm{CV}=$ coefficient of variation; ${ }^{\mathrm{NS}}=$ not significant $(\mathrm{p}>0.05) ;{ }^{*}=$ significant $(\mathrm{p} \leq 0.01) ;{ }^{*}=$ significant $(\mathrm{p}$ $\leq 0.05)$.

A greater influence of defoliation level treatments was observed on the reproductive stages particularly on total defoliation treatment (T5, T7 and T 11).

The objective of total defoliation treatment is to simulate the severe attack of soybean rust, whose main loss is the early fall of the leaves and, consequently, the reduction of the mass of grains, by the reduction in the source, thus damaging the productivity of the crop (Yang et al., 2001). Such situation was also observed at defoliation insects attack, as the limitation of leaf area causes a smaller production of photoassimilates, therefore, compromising the adequate grain filling (Timsina et al., 2007).

A higher reduction in the height was observed (28\% in relation to the control treatment, without defoliation), when they underwent total defoliation at the R5 stage, and a reduction by 10 and $18 \%$ in the treatments (T7 and T11), respectively. In the other treatments, the mean values were lower, but not significant in relation to the control.

For plant height, interaction between cultivars and defoliation level (Figure 1). No difference was observed between BRS8890 RR and BRS 9090 RR cultivars, except for T3, T5 and T9 treatments, which showed a difference. 


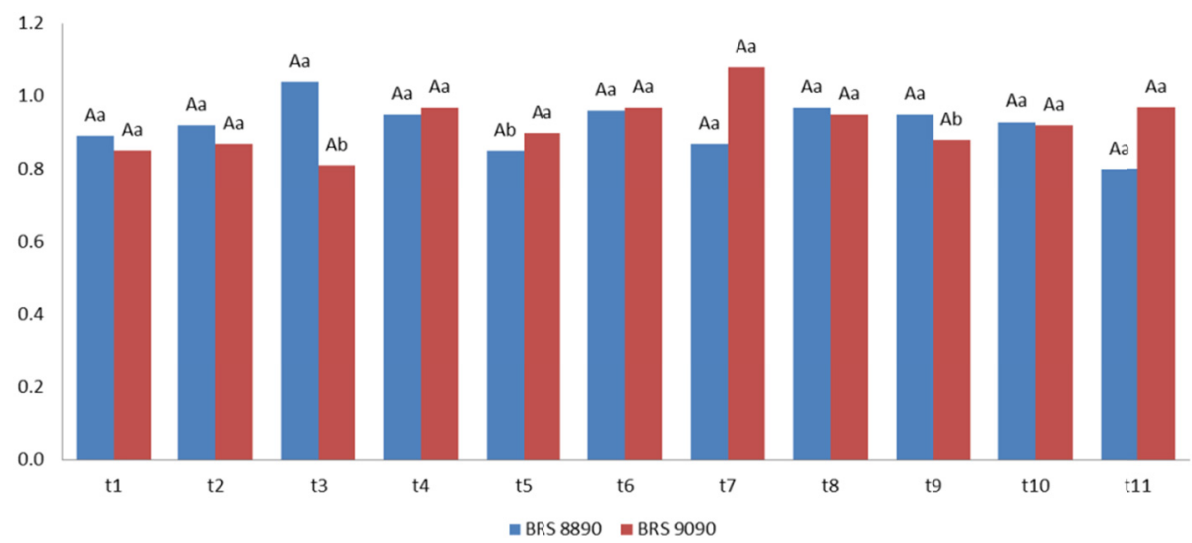

Figure 1. Unfolding between defoliation levels and cultivars for plant height variable

Note. Lower-case levels compare cultivars in each treatment and the upper-case letter compare treatments in each cultivar.

The reduction in plant height is directly related to the percentage of defoliation. Where the defoliation of the soybean in its vegetative period has little effect on its production, mainly due to the great capacity of recovery of the plant in that period, that emits many new leaves.

The soybean cultivars used in the experiment tolerate a certain defoliation index, providing the remaining leaves a greater efficiency in the photosynthetic rate when compared to the non-defoliation plants ( $\mathrm{Li}$ et al., 2006).

The stem diameter (SD), as well as the plant height, showed statistically equal values for all treatments, plus a reduction of $14 \%$ in the $\mathrm{T} 7$ treatment (total defoliation-R1 stage) in relation to the control. This explains that besides the capacity of recovery of soybean, one must also consider that the plant has the characteristic of producing excess of leaf area.

For the cultivar factor, the number of leaves (NL) was significant, in which the cultivar BRS 8890 RR showed about 35\% more leaves than BRS 9090 RR. This was also observed for width of roots, therefore, showing that besides the short-term changes in the distribution of photo-assimilates between the different drains (roots, nodules, expanding leaves, grains), the source metabolism adjusts to the altered conditions in long-term experiments.

Table 3 shows for the cultivar treatment a significance for the variables, productivity (PRODUT), dry stem mass (DSM) and root fresh mass (RFM). Nevertheless, for defoliation levels and interaction between cultivars, no significance was observed. 
Table 3. Summary of analysis of variance and means of data on Productivity (PRODUT), Pod Fresh Mass (PFM), PDM-Pod Dry Mass; FSM-Fresh Stem Mass; DSM-Dry Stem Mass; FLM-Fresh Leaf Mass; DLM-Dry Leaf Mass; FRM-Fresh Root Mass; DRM-Dry Root Mass

\begin{tabular}{|c|c|c|c|c|c|c|c|c|c|c|}
\hline Variation Factors & & PRODUT & MVF & MVS & $\mathrm{MCF}$ & MCS & MFF & MFS & MRF & MRS \\
\hline \multirow{3}{*}{ Cultivars $(\mathrm{C})$} & & $\mathrm{kg} \mathrm{ha}^{-1}$ & \multicolumn{8}{|c|}{ 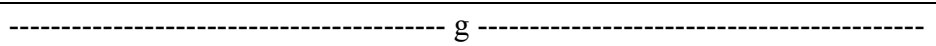 } \\
\hline & 8890 & $3954.30 \mathrm{a}$ & 51.7 & $12.99 \mathrm{a}$ & 84.56 & $28.54 \mathrm{a}$ & 55.93 & 13.63 & $55.12 \mathrm{a}$ & 6.79 \\
\hline & 9090 & $2894.42 \mathrm{~b}$ & 51.2 & $9.14 b$ & 88.57 & $17.69 \mathrm{~b}$ & 54.08 & 13.69 & $47.10 \mathrm{~b}$ & 6.70 \\
\hline \multirow{11}{*}{ Defoliation level (ND) } & $\mathrm{T} 1$ & 5053.00 & 47.8 & 15.81 & 110.87 & 38.57 & 78.96 & 26.97 & 60.86 & 7.81 \\
\hline & $\mathrm{T} 2$ & 4105.67 & 47.8 & 13.99 & 96.62 & 34.28 & 73.71 & 24.67 & 56.41 & 7.24 \\
\hline & $\mathrm{T} 3$ & 4091.67 & 47.1 & 12.69 & 95.62 & 27.19 & 58.79 & 14.98 & 54.98 & 5.13 \\
\hline & $\mathrm{T} 4$ & 3860.67 & 44.4 & 12.61 & 92.36 & 26.64 & 57.69 & 12.73 & 54.59 & 7.53 \\
\hline & $\mathrm{T} 5$ & 2271.67 & 38.4 & 8.00 & 70.66 & 14.45 & 24.01 & 10.32 & 53.54 & 6.08 \\
\hline & $\mathrm{T} 6$ & 3586.67 & 43.7 & 11.51 & 88.86 & 22.65 & 52.67 & 11.86 & 53.54 & 6.08 \\
\hline & $\mathrm{T} 7$ & 2507.33 & 40.6 & 7.47 & 70.38 & 18.64 & 28.83 & 11.33 & 49.78 & 6.95 \\
\hline & $\mathrm{T} 8$ & 3576.33 & 44.3 & 9.41 & 80.66 & 19.28 & 38.82 & 10.75 & 49.20 & 7.20 \\
\hline & T9 & 3411.00 & 40.1 & 8.02 & 75.10 & 18.92 & 45.24 & 10.70 & 48.03 & 6.23 \\
\hline & $\mathrm{T} 10$ & 3193.00 & 39.6 & 8.02 & 69.73 & 17.29 & 43.02 & 8.12 & 45.12 & 5.96 \\
\hline & $\mathrm{T} 11$ & 2011.00 & 35 & 5.37 & 64.46 & 15.37 & 22.34 & 7.89 & 40.84 & 7.30 \\
\hline \multirow{3}{*}{ Test F } & $\mathrm{C}$ & $13115^{* *}$ & $0.029^{\mathrm{NS}^{-}}$ & $6.65^{*}$ & $0.25^{\mathrm{N} \bar{S}^{-}}$ & $16.24^{*}$ & $0.031^{\mathrm{NS}}$ & $0.00^{\mathrm{NS}^{-}}$ & $5.23^{*-1}$ & $0.06^{\mathrm{NS}^{-}}$ \\
\hline & ND & $3406^{*}$ & $0.57^{\mathrm{NS}}$ & $1.36^{\mathrm{NS}}$ & $1.01^{\mathrm{NS}}$ & $1.63^{\mathrm{NS}}$ & $0.74^{\mathrm{NS}}$ & $1.54^{\mathrm{NS}}$ & $1.13^{\mathrm{NS}}$ & $1.79^{\mathrm{NS}}$ \\
\hline & $\mathrm{C} \times \mathrm{ND}$ & $1923^{\mathrm{NS}}$ & $0.39^{\mathrm{NS}}$ & $0.61^{\mathrm{NS}}$ & $1.82^{\mathrm{NS}}$ & $1.24^{\mathrm{NS}}$ & $0.68^{\mathrm{NS}}$ & $1.30^{\mathrm{NS}}$ & $1.87^{\mathrm{NS}}$ & $2.40^{\mathrm{NS}}$ \\
\hline CV $(\%)$ & & 11.14 & 10.01 & 24.76 & 13.36 & 16.24 & 17.28 & 13.63 & 9.87 & 21.84 \\
\hline
\end{tabular}

Note. $\mathrm{CV}=$ coefficient of variation; not significant $(\mathrm{p}>0.05) ; * *=$ significant $(\mathrm{p} \leq 0.01) ; *=$ significant $(\mathrm{p} \leq$ $0.05)$.

Defoliation after vegetative stages resulted in a reduction in grain yield, in the dry mass of the pods, stems, leaves and roots. This reduction increased as the level of defoliation increased, except in the T5 treatment, which was a total defoliation at the end of the vegetative stage (Table 3).

Considering the level of defoliation within the period, it was verified that there were no significant reductions in grain yield, in relation to the control, for defoliation that occurred in the first stages of vegetative development. The exception was T5 treatment, which had a total defoliation.

The highest reductions, $60 \%, 55 \%$ and $50 \%$, occurred when the defoliation was $100 \%$ in treatments T11-stage R5, T5-stage V6 and T7-stage R1 in relation to the control, identifying in the plants in the phenological phase of complete pod formation.

Defoliations after the vegetative stage caused, in general, a reduction in the grain yield. Such reduction increases as the level and the season of defoliation increases, in the defoliation treatments in relation to the control. Smaller productivity occurred in T11 total defoliation in R5-beginning of grain filling.

Authors point out the early defoliation, especially over the reproductive phase of the crop as an important factor and that it may limit the final productivity (Pratissoli et al., 2001; Parcianello et al., 2004; Peluzio et al., 2004; Fontoura et al., 2006).

The treatments performed in the vegetative stages submitted to defoliation presented higher productive index. Soybean tolerates defoliation, providing to the remaining leaves, a greater efficiency in the photosynthetic rate when compared to plants without defoliation, especially when submitted to some abiotic stress ( $\mathrm{Li}$ et al., 2006). This higher photosynthetic efficiency contributed to the higher maintenance of vegetables near these more active leaves, which may have occurred in the study.

For Shibles et al. (1975), the defoliation changes the source/drain ratio, causing the plant to undergo a rearrangement of the physiological functions. Pissaia et al. (1982) mention that levels of defoliation cause competition in the plant between reproductive and vegetative parts. New leaves are formed at the expense of carbohydrates that would be used in the formation of the pods. This competition is more pronounced as defoliation levels increase, leading to further reductions in grain yield. 
Studies have shown that defoliation of less than $50 \%$ before flowering does not normally reduce grain yield, whereas during reproductive stages, it has caused greater reductions in soybean yield (Bueno et al., 2010).

However, the capacity of the soybean to avoid reduction in the productivity after defoliation depends on factors such as the defoliation intensity itself, the phenological stage in which it occurs, the ability of the cultivar to tolerate or to compensate for defoliation (Costa et al., 2003; Parcianello et al., 2004) besides the environmental factors, among them, the solar radiation (Andrade et al., 2002).

\section{Conclusions}

In their early stages of development, soybean plants have a great recovery capacity in relation to defoliation, and reductions in the production are only caused when the defoliation is sufficient to cause the death of the plant, therefore, significantly reducing the plant stand. This reduction in the stand only happened with the occurrence of intense injuries, that is, when $100 \%$ defoliation occurs. Levels of defoliation and the period of leaf removal significantly influenced the number of pods per plant, the mass of one hundred seeds and the yield of grains. Thus, treatments T11, T7 and T5, where the total removal of leaves occurred, showed the largest decreases in grain yield.

It was found in this work that cultivar BRS 8890 RR showed the best results, approximately $27 \%$ more productive than the cultivar BRS 9090 RR.

\section{References}

Andrade, F. H., Calviño, P., Cirilo, A., \& Barbieri, P. (2002). Yield responses to narrow rows depend on increased radiation interception. Agronomy Journal, 94(5), 975-980. https://doi.org/10.2134/agronj 2002.0975

Brasil, Ministério da Agricultura, Pecuária e Abastecimento. (2009). Regras Para Análise de Sementes (p. 365). Brasília: Dndv/Clav.

Bueno, A. F., Batistela, M., Moscardi, F., Bueno, R. C. O. F., Nishikawa, M., Hidalgo, G., ... Silva, R. B. (2010). Níveis de Desfolha Tolerados na Cultura da Soja Sem a Ocorrência de Prejuizos à Produtividade (Circular Técnica, 79, p. 12). Londrina: Embrapa-Cnpso.

Costa, M. A. G., Balardin, R. S., Costa, E. C., Grützmacher, A. D., \& Silva, M. T. B. (2003). Níveis de desfolha na fase reprodutiva da soja, cv Ocepar 14, sobre dois sistemas de cultivo. Ciência Rural, 33(5), 813-819. https://doi.org/10.1590/S0103-84782003000500004

Debona, D., Figueiró, G. G., Corte, G. D., Navarini, L., Dominges, L. da S., \& Balardin, R. S. (2009). Efeito do tratamento de sementes com fungicidas e acibenzolar-S-methyl no controle da ferrugem asiática e crescimento de plântulas em cultivares de soja. Summa Phytopathology, 35(1), 26-31. https://doi.org/ 10.1590/S0100-54052009000100004

EMBRAPA (Empresa Brasileira de Pesquisa Agropecuária). (1997). Manual de métodos de análise de solo (2nd ed.). Rio de Janeiro, RJ: Embrapa, Centro Nacional de Pesquisa de Solos.

EMBRAPA (Empresa Brasileira de Pesquisa Agropecuária). (2008). Tecnologias de produção de soja-Região Central do Brasil-2009-2010. Sistemas de Produção/Embrapa Soja (No. 13, p. 262). Londrina: Embrapa Agropecuária Oeste.

EMBRAPA (Empresa Brasileira de Pesquisa Agropecuária). (2011). Tecnologias de produção de soja-região central do Brasil-2012 e 2013. Embrapa Soja. Sistemas de Produção (No. 15, p. 262). Londrina: Embrapa Soja, Embrapa Cerrados.

Fazolin, M., \& Estrela, J. L. V. (2003). Comportamento da cv. Pérola (Phaseolus vulgaris) submetida a diferentes níveis de desfolha artificial. Ciência Agrotécnica, 27(5), 978-984. https://doi.org/10.1590/S1413-70542003 000500002

Fehr, W. R., \& Caviness, C. E. (1977). Stages of soybean development (Special Report, No. 80, p. 11). Ames, Yowa: Yowa State University of Science and Technology, Cooperative Extension Service.

Ferreira, D. F. (2014). Sisvar: A guide for its bootstrap procedures in multiple comparisons. Ciência $e$ Agrotecnolgia, 38(2), 109-112. https://doi.org/10.1590/S1413-70542014000200001

Fontoura, T. B., Costa, J. A., \& Daros, E. (2006). Efeito de níveis e épocas de desfolhamento sobre o rendimento e os componentes do rendimento de grãos da soja. Scientia Agraria, 7(1-2), 49-54. https://doi.org/10.5380/ rsa.v7i1.7271 
Gazzoni, D. L. (1974). Avaliação do efeito de três níveis de desfolha aplicadas em 4 estádios de crescimento de dois cultivares de soja (Glycine max (L) Merrill) sobre a produção e a qualidade de grão (p. 70, Dissertação (Mestrado), Universidade Federal do Rio Grande do Sul, Porto Alegre).

Gee, G. W., \& Bauder, J. W. (1986). Particle-size analysis. In A. Klute (Ed.), Methods of soil analysis. Part 1. Physical and mineralogical methods (2nd ed.). Madison, American Society of Agronomy, Soil Science Society of America.

Li, X., An, S., Eneji, A. E., \& Tanabe, K. (2006). Salinity and defoliation effects on soybean growth. Journal of Plant Nutrition, 29(8), 1499-1508. https://doi.org/10.1080/01904160600837642

Ostlie, K. R., \& Pedigo, L. P. (1985). Soybean response to simulated green cloverworm (Lepidoptera: Noctuidae) defoliation: Progress towards determining comprehensive economic injury levels. Journal of Economic Entomology, 78(2), 437-444. https://doi.org/10.1093/jee/78.2.437

Parcianello, G., Costa, J. A., Pires, J. L. F., Rambo, L., \& Saggin, K. (2004). Tolerância da soja ao desfolhamento afetada pela redução do espaçamento entre fileiras. Ciência Rural, 34(2), 357-364. https://doi.org/ $10.1590 / \mathrm{S} 0103-84782004000200004$

Pedigo, L. P., Hutchins, S. H., \& Higley, L. G. (1986). Economic injury levels in theory and practice. Annual Review of Entomology, 31, 341-368. https://doi.org/10.1146/annurev.en.31.010186.002013

Peluzio, J. M., Barros, H. B., Brito, E. L., Santos, M. M. dos, \& Silva, R. R. da. (2004). Efeitos sobre a soja do desfolhamento em diferentes estádios fenológicos. Revista Ceres, 51(297), 575-585.

Peluzio, J. M., Barros, H. B., Rocha, R. N. C., Silva, R. R. da, \& Nascimento, I. R. do. (2002). Influência do desfolhamento artificial no rendimento de grãos e componentes de produção da soja (Glycine max (L.) Merrill). Ciência Agrotécnica, 26(6), 1197-1203.

Pissaia, A., \& Costa, J. A. (1982). Influência de desfolhamentos artificiais sobre o rendimento de grãos e seus componentes, em duas cultivares de soja. Pesquisa Agropecuária Brasileira, 3(4), 47-61.

Pratissoli, D., Schmildt, E. R., Reis, E. F., \& Thuler, R. T. (2001). Influência de desfolhas simuladas na produtividade e em outras características agronômicas do feijoeiro. Revista Ceres, 48(275), 17-24.

Ribeiro, A. L. P., \& Costa, E. C. (2000). Desfolhamento em estádios de desenvolvimento da soja, cultivar BR 16, no rendimento de grãos. Ciência Rural, 30(5), 767-771. https://doi.org/10.1590/S0103-84782000000 500004

Santos, F. F. (1980). Efeitos do nível de desfolha no rendimento de grãos e em outras características agronômicas de duas variedades de soja (Glycine max (L.) Merrill) (p. 37, Dissertação (Mestrado), Universidade Federal de Viçosa, Viçosa).

Santos, F. F. (1983). Efeitos da retirada de vagens, desfolha e corte de plantas no rendimento de grãos e em outras características agronômicas de soja (Glycine max (L.) Merrill) (p. 90, Tese (Doutorado), Universidade Federal de Viçosa, Viçosa).

Shibles, R. M., Anderson, I. C., \& Gibson, A. H. (1975). Soybean. In L. T. Evans (Ed.), Crop phisiology: Some case histories (pp. 151-189). London: Cambridge University.

Timsina, J., Boote, K. J., \& Duffield, S. (2007). Evaluating the Cropgro soybean model for predicting impacts of insect defoliation and depodding. Agronomy Journal, 99, 148-157. https://doi.org/10.2134/agronj2005.0338

Yang, X. B., Tschanz, A. T., Dowler, W. M., \& Wang, T. C. (2001). Development of yield loss models in relation to reductions of components of soybeans infected with Phakopsora pachyrhizi. Phytopathology, 81, 1420-1426. https://doi.org/10.1094/Phyto-81-1420

\section{Copyrights}

Copyright for this article is retained by the author(s), with first publication rights granted to the journal.

This is an open-access article distributed under the terms and conditions of the Creative Commons Attribution license (http://creativecommons.org/licenses/by/4.0/). 